\title{
Analisis Karakteristik Penggunaan Aplikasi Peer To Peer Lending Fintech dengan Model PCI
}

\author{
Syarifah $^{1, *}$, Wing Wahyu Winarno ${ }^{2}$, Hanson Prihantoro Putro ${ }^{1}$ \\ ${ }^{1}$ Jurusan Teknik Informatika, Fakultas Teknologi Industri, Universitas Islam Indonesia, Yogyakarta, Indonesia \\ ${ }^{2}$ Sekolah Tinggi Ilmu Ekonomi YKPN, Yogyakarta, Indonesia \\ E-Mail: 1,*16917225@students.uii.ac.id, ${ }^{2} w i n g @ s t i e y k p n . a c . i d,{ }^{3}$ hanson@uii.ac.id \\ Email Penulis Korespondensi: 16917225@students.uii.ac.id
}

\begin{abstract}
Abstrak-Penelitian ini bertujuan untuk mengetahui karakteristik yang mempengaruhi intensi penggunaan aplikasi Peer to peer lending fintech dengan model Perceived Characteristics of Innovation (PCI). Penelitian ini dilakukan terhadap 203 responden yang menggunakan aplikasi peer to peer lending fintech dan 114 responden yang tidak menggunakan aplikasi Peer to peer lending fintech di Indonesia. Hasil dari penelitian ini menunjukkan bahwa karateristik inovasi relative advantage, complexity, dan observability dapat menjadi faktor penentu intensi masyarakat dalam menggunakan aplikasi Peer to peer lending Fintech. Karakteristik lainnya compatibility dan trialability tidak dapat menjadi prediktor minat masyarakat dalam menggunakan layanan peer to peer lending fintech. Terdapat faktor lain pada masyarakat yang tidak menggunakan aplikasi peer to peer lending fintech bahwa sebagian besar masyarakat tidak tertarik menggunakan aplikasi. Beberapa merasa aplikasi peer to peer lending bertentangan dengan agama. Sebagian besar alasan lainnya adalah mereka belum pernah mendengar tentang aplikasi tersebut dan masyarakat merasakan rumitnya menggunakan aplikasi peer to peer lending fintech.
\end{abstract}

Kata Kunci: Peer to peer lending; Financial Technology, Perceived Characteristics of Innovation, Intensi

\begin{abstract}
This study aims to determine the characteristics that influence the intention to use Peer to peer lending fintech applications with the Perceived Characteristics of Innovation (PCI) model. This study was conducted on 203 respondents who used the peer to peer lending fintech application and 114 respondents who did not use the Peer to peer lending fintech application in Indonesia. The results of this study indicate that the characteristics of innovation relative advantage, complexity, and observability can be determinants of people's intentions in using the Peer to peer lending application Fintech. Other characteristics of compatibility and trialability cannot be predictors of public interest in using peer to peer lending fintech services. There are other factors in people who do not use peer to peer lending fintech applications that most people are not interested in using applications. Some feel the application of peer to peer lending is against religion. Most of the other reasons are that they have never heard of the application and the public feels the complexity of using the peer to peer lending fintech application.
\end{abstract}

Keyword: Peer to peer lending; Financial Technology, Perceived Characteristics of Innovation, Intention

\section{PENDAHULUAN}

Financial Technology (fintech) saat ini mengalami perkembangan dan termasuk layanan keuangan terbaik jika dibandingkan dengan model tradisional [1]. Fintech merupakan fenomena penting yang harus diamati oleh para pelaku yang terkait dengan industri keuangan, teknologi informasi (TI) dan inovasi [2] . Fintech hadir berinovasi dalam bentuk platform Peer to peer lending atau disebut dengan kredit online untuk memudahkan masyarakat. Beberapa platform Peer to peer lending di Indonesia yang banyak dikenalkan oleh masyarakat, di antaranya yaitu KreditPintar, KreditCepat, Modalku, Akulaku, HomeCredit, KreditPlus, Uangteman, Tunaikita, dan lainlain. Dari beberapa jenis fintech di Indonesia saat ini, Peer to peer lending merupakan jenis fintech yang paling menarik untuk dianalisa perkembangan dan peluangnya [3]. Otoritas Jasa Keuangan (OJK) mencatat jumlah penyaluran pinjaman Peer to peer lending per juni 2019 mencapai Rp 44,80 triliun [4]. Berdasarkan Laporan Fintech (2018) dari 1419 responden, pengguna menyebutkan alasan menggunakan fintech. Alasan tersebut yaitu fintech mudah digunakan, simpel, efisien, tidak perlu datang ke Bank, aman, adanya promo, sampai pada manajemen lebih baik.Kemudahan yang ditawarkan oleh peer to peer lending fintech berdampak pada perusahaan startup di Indonesia.

Akhir-akhir ini, banyak kemunculan platform yang belum terdaftar Otoritas Jasa Keuangan (OJK). Sejumlah 114 dari 947 platform peer to peer lending ilegal di Indonesia telah ditutup [6]. Salah satu user incash telah dipermalukan oleh pihak layanan tersebut karena terlambat membayar pinjaman dengan cara yang tidak manusiawi [7]. Selain itu, marak terjadi masyarakat tercekik pinjaman online di berbagai platform fintech. Hal itu disebabkan kemudahkan akses layanan peer to peer lending atau bahkan tergiur pinjaman online hanya karena ujicoba dan dana cepat cair dalam waktu 5 menit. Dengan demikian menyebabkan tidak sedikit masyarakat yang mengalami tunggakan di berbagai platform peer to peer lending.

Rangkaian kejadian di atas telah menyebabkan kerugian pada perusahaan fintech dan pengguna fintech itu sendiri. Banyak informasi tentang fintech, justru membuat terjadi penurunan dalam penggunaan fintech seperti yang terjadi pada 2018 meski tidak terlalu signifikan [5]. Tingkat kepercayaan masyarakat menjadi kurang terhadap fintech. Perusahaan startup menjadi kurang optimal dalam menentukan target dalam pemasaran fintechnya. Selain itu juga kebingungan dalam peningkatan kualitas sistem aplikasi Peer to peer lending, karena tidak diketahui secara pasti faktor yang mempengaruhi user untuk menggunakan kembali fintech atau untuk menggunakan fintech pertama kali bagi pengguna baru. Berdasarkan permasalahan tersebut, maka perlu 
dilakukan penelitian mengenai karakteristik inovasi dari aplikasi peer to peer lending fintech. Hal ini sangat penting pada tahap awal adopsi sehingga tidak berdampak buruk pada user seperti yang sudah banyak terjadi di Indonesia. Selain itu, juga perlu melihat faktor-faktor yang mempengaruhi tingkat penggunaan user terhadap fintech.

Model Perceived Characteristics of Innovation (PCI) akan digunakan dalam pengukuran intensi penggunaan aplikasi Peer to peer lending fintech. Rogers (2003) mengemukakan bahwa terdapat lima karakteristik yang sangat penting untuk mencapai tingkat adopsi yang cepat dan sukses secara keseluruhan di pasar, diantaranya adalah relative advantage, compatibility, complexity, trialability, dan observability. Mengetahui karakteristik apa saja yang mempengaruhi intensi penggunaan aplikasi peer to peer lending fintech dan faktor-faktor yang menyebabkan non user tidak menggunakan aplikasi peer to peer lending fintech menjadi hasil akhir penelitian ini. Perusahaan startup dapat melihat target fintech dan dapat mengembalikan kepercayaan user kepada aplikasi fintech. Evaluasi aplikasi fintech membuat tidak sembarang user atau hanya user yang benar-benar ingin meminjam yang dapat diterima pinjamannya.

Penelitian ini diharapkan dapat menjadi parameter alternatif dalam meningkatkan layanan pengembangan aplikasi Peer to peer lending sebagai bahan evaluasi perusahaan startup untuk memperbaiki kekurangan pada platform. Bagi masyarakat dan pembaca diharapkan penelitian ini dapat memberikan ilmu dan manfaat tentang Peer to peer lending fintech.

\section{METODE PENELITIAN}

Metodologi yang dilakukan dalam penelitian ini melalui beberapa tahapan proses penelitian seperti yang disajikan pada . Pertama, studi literatur terkait dengan financial technology, peer to peer Lending, model perceived characteristics of innovation, dan metode statistik regresi berganda untuk menunjang penelitian. Kedua, menentukan sampel dan mengumpulkan data dengan kuesioner. Sampel yang digunakan penelitian ini adalah 203 responden untuk user dan 114 responden untuk non user. Indikator dan desain penelitian dalam penelitian ini mengacu pada indikator Sugandini dalam [9] seperti yang ditampilkan pada Tabel 1. Ketiga, menganalisis data dilakukan dengan alat bantu aplikasi SPSS 25.0 setelah menghetahui hasil angka-angka statistik kemudian dideskripsikan untuk menjawab hipotesis pada penelitian ini sehingga dapat membuat kesimpulan yang berkaitan dengan karakteristik yang mempengaruhi penggunaan aplikasi peer to peer Lending fintech.

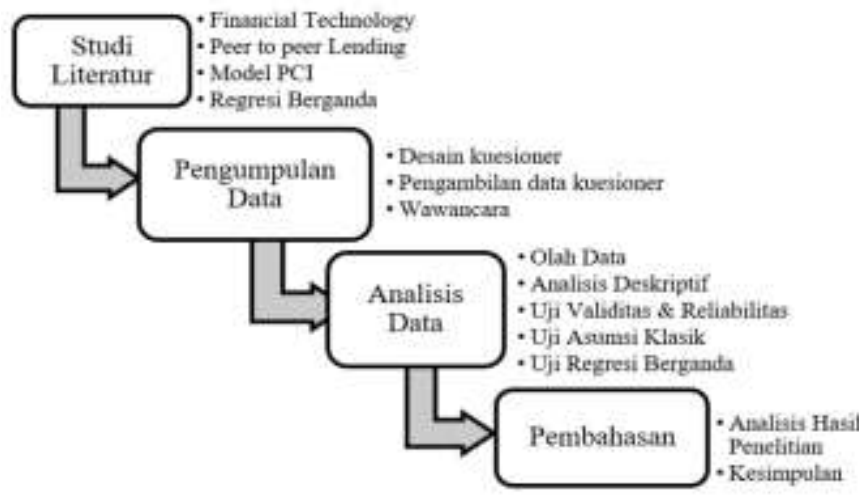

Gambar 1. Workflow Metode Penelitian

Tabel 1. Desain Kuesioner

\begin{tabular}{|c|c|c|}
\hline Variabel & Kode & Indikator \\
\hline \multirow[t]{5}{*}{$\begin{array}{l}\text { Relative } \\
\text { advantage }\end{array}$} & RA1 & $\begin{array}{l}\text { Dengan menggunakan aplikasi peer to peer lending, dapat menghemat biaya, waktu serta } \\
\text { tenaga. }\end{array}$ \\
\hline & RA2 & $\begin{array}{l}\text { Aplikasi peer to peer lending lebih nyaman dibandingkan dengan cara peminjaman } \\
\text { tradisional. }\end{array}$ \\
\hline & RA3 & Aplikasi peer to peer lending menjamin keamanan data privacy. \\
\hline & RA4 & Aplikasi peer to peer lending cepat memproses peminjaman dana. \\
\hline & RA5 & $\begin{array}{l}\text { Aplikasi peer to peer lending lebih mudah digunakan dibandingkan dengan peminjaman } \\
\text { lain yang harus bertatap muka, seperti: Bank atau Koperasi Unit. }\end{array}$ \\
\hline \multirow[t]{3}{*}{ Compatibility } & CPT1 & $\begin{array}{l}\text { Aplikasi peer to peer lending yang digunakan bunga dan tagihannya sesuai dengan } \\
\text { kebutuhan. }\end{array}$ \\
\hline & CPT2 & $\begin{array}{l}\text { Aplikasi peer to peer lending yang persyaratan dan tahap transaksi yang digunakan cocok } \\
\text { dengan gaya hidup. }\end{array}$ \\
\hline & СРT3 & $\begin{array}{l}\text { Aplikasi peer to peer lending yang digunakan tidak bertentangan dengan keyakinan } \\
\text { (agama). }\end{array}$ \\
\hline
\end{tabular}




\begin{tabular}{|c|c|c|}
\hline & CPT4 & er to peer lending yang digunakan sepenuhnya kompatibel. \\
\hline \multirow{4}{*}{ Complexity } & CX1 & Aplikasi peer to peer lending rumit digunakan \\
\hline & $\mathrm{CX} 2$ & Aplikasi peer to peer lending sulit untuk dipahami \\
\hline & CX3 & Menggunakan aplikasi peer to peer lending sulit membayar tagihan \\
\hline & CX4 & $\begin{array}{l}\text { Aplikasi peer to peer lending hanya dapat digunakan oleh kalangan kalangan tertentu saja } \\
\text { atau tidak semua orang dapat menggunakannya. }\end{array}$ \\
\hline \multirow[t]{2}{*}{ Trialability } & TL1 & Aplikasi peer to peer lending menyediakan layanan uji coba transaksi untuk pemula \\
\hline & TL2 & $\begin{array}{l}\text { Aplikasi peer to peer lending menyediakan tutorial penggunaan aplikasi baik berupa } \\
\text { dokumen maupun video. }\end{array}$ \\
\hline \multirow[t]{3}{*}{ Observability } & OB1 & Aplikasi peer to peer lending mudah untuk dieksplore dari semua fitur yang ada. \\
\hline & OB2 & $\begin{array}{l}\text { Aplikasi peer to peer lending mudah untuk dikomunikasikan kepada orang lain agar dapat } \\
\text { melakukan transaksi peminjaman online. }\end{array}$ \\
\hline & OB3 & Orang lain merasakan manfaat yang sama pada aplikasi yang digunakan \\
\hline \multirow[t]{4}{*}{ Intensi } & INT1 & Saya tertarik menggunakan aplikasi peer to peer lending untuk peminjaman dana. \\
\hline & INT2 & Saya bersedia mendownload aplikasi peer to peer lending \\
\hline & INT3 & Menggunakan aplikasi kredit online menurut saya adalah keputusan yang tepat \\
\hline & INT4 & $\begin{array}{l}\text { Saya berniat untuk menggunakan aplikasi peer to peer lending untuk kredit lagi di periode } \\
\text { yang akan datang. }\end{array}$ \\
\hline
\end{tabular}

\subsection{Kajian Teori}

Financial Technology lebih fokus pada perusahaan yang melakukan inovasi di bidang jasa keuangan dengan sentuhan teknologi modern. Kesimpulan dari beberapa definisi dengan analisis semantik, fintech yaitu suatu industri keuangan yang tergolong baru dengan menerapkan teknologi untuk meningkatkan kegiatan keuangan [10]. Beragam fintech yang ada di Indonesia di antaranya adalah penggalangan dana, pengelolaan aset, payment gateway, e-money, Peer to peer lending, remittance, saham, dan asuransi [11].

Definisi peer to peer lending ialah sebuah proses yang menjalankan peminjaman berupa uang melalui platform online antara dua individu yang secara langsung tidak bersangkutan, tanpa campur tangan dari perantara keuangan yang tradisional, misalnya Bank [12]. Definisi lain mengatakan bahwa peer to peer lending yaitu suatu inovasi bidang keuangan di Indonesia menggunakan platform layaknya pada perusahaan ecommerce, platform ini mempertemukan pemberi pinjaman dengan para peminjam secara online. Hal ini merupakan suatu gambaran bahwa Indonesia sangat inovatif dalam perkembangannya pada lembaga keuangan[13]. Indonesia terdapat beberapa aplikasi peer to peer lending yang 24 jam yang cepat memproses pencairan dana dan terpercaya, di antaranya seperti: akulaku, traveloka paylater, kreditpintar, homecredit, kredivo, danacepat, kreditcepat, tunaiku, cicil, incash, dan sebagainya.

PCI merupakan salah satu elemen dari teori difusi inovasi sebagai suatu proses penyaluran atau komunikasi sebuah inovasi dalam masyarakat dari waktu ke waktu [8]. Ia menjelaskan bahwa kecepatan sebuah inonvasi dipengaruhi oleh empat elemen yaitu karakteristik inovasi, kanal komunikasi yang digunakan untuk mengkomunikasikan manfaat inovasi, waktu pertama inovasi diperkenalkan, dan sistem sosial tempat inovasi berdifusi. Semakin besar dan sulit sebuah inovasi, maka akan semakin lama waktu yang dibutuhkan dalam difusi. Ia mencontohkan sebuah adopsi difusi internet pada masyarakat membutuhkan waktu yang lebih lama daripada difusi botol susu bayi karena dirasakan jauh lebih sederhana daripada internet [14]. Karakteristik umum sebuah inovasi yang mempengaruhi kecepatan difusi diantaranya yaitu relative advantage, compatibility, complexity, trialability, dan observability. Model tersebut dari tahun ke tahun telah banyak digunakan peneliti untuk menguji adopsi inovasi.

\subsection{Model Penelitian}

Model dalam penelitian ini adalah mengacu pada model yang dikembangkan Rogers (1995) di mana model ini telah banyak digunakan oleh peneliti sebelumnya. Model ini digunakan untuk menjawab rumusan masalah terkait dengan karakteristik apa saja yang mempengaruhi intensi penggunaan aplikasi peer to peer lending fintech. Model penelitian yang dapat dilihat pada Gambar 1.

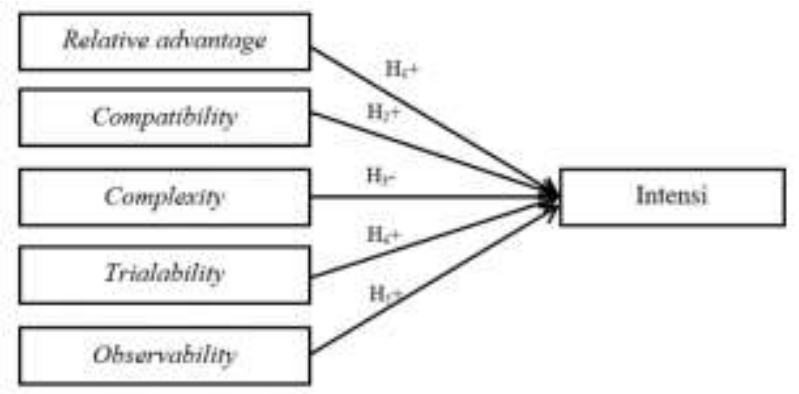

Gambar 2. Model Penelitian 
JURNAL MEDIA INFORMATIKA BUDIDARMA

Volume 4, Nomor 2, April 2020, Page 421-428

ISSN 2614-5278 (media cetak), ISSN 2548-8368 (media online)

Available Online at https://ejurnal.stmik-budidarma.ac.id/index.php/mib DOI $10.30865 /$ mib.v4i2.2059

\subsection{Analisis Data}

Dalam penelitian ini akan digunakan dua kelompok data, yaitu data user dan non user. Untuk data user, akan dianalisa secara kuantitatif di mana bentuk analisis yang penyajiannya dalam angka-angka yang dapat diukur dan dihitung [16]. Sedangkan untuk analisa data non user akan ditampilkan hasil statistik deskriptif kemudian dirangking hasil nilai tertinggi (terbanyak). Dalam analisa data user digunakan analisa regresi berganda. Uji Regresi berganda meliputi tahap-tahap sebagai berikut: uji validitas dan reliabilitas, uji asumsi klasik, kemudian uji regresi berganda. Analisa tersebut dilakukan untuk membuktikan hipotesis penelitian ini.

\section{HASIL DAN PEMBAHASAN}

\subsection{Demografi Responden}

Berdasarkan data responden dapat diketahui bahwa sebagian besar pengguna aplikasi peer to peer lending berjenis kelamin perempuan. Berdasarkan usia, diketah ui bahwa responden terbanyak 95 responden pengguna aplikasi peer to peer lending berusia 31-40 tahun. Berdasarkan jumlah penghasilan, dapat diketahui bahwa sebagian besar jumlah penghasilan responden pada penelitian ini sebesar 3-4 juta yang berjumlah 73 responden dan berdasarkan aplikasi yang sering digunakan dapat diketahui bahwa Sebagian besar responden menggunakan aplikasi kreditpintar seperti yang ditampilkan pada Tabel 2.

Tabel 2. Demografi Responden User

\begin{tabular}{llcc}
\hline & & & \\
\hline \multirow{2}{*}{ Jenis Kelamin } & Laki-laki & 73 & $36 \%$ \\
& Perempuan & $\mathbf{1 3 0}$ & $\mathbf{6 4 \%}$ \\
\hline \multirow{2}{*}{ Usia } & $20-25$ th & 18 & $9 \%$ \\
& $26-30$ th & 74 & $37 \%$ \\
& $\mathbf{3 1 - 4 0 t h}$ & $\mathbf{9 5}$ & $\mathbf{4 7 \%}$ \\
& $41-50$ th & 13 & $6 \%$ \\
& $>50$ th & 2 & $1 \%$ \\
\hline \multirow{2}{*}{ Jumlah Penghasilan } & $<$ Rp 1jt & 9 & $4 \%$ \\
& Rp 1jt - 2jt & 27 & $13 \%$ \\
& Rp 2jt - 3jt & 35 & $16 \%$ \\
& Rp 3jt - 4jt & $\mathbf{7 3}$ & $\mathbf{3 5 \%}$ \\
& $>$ Rp 4jt & 68 & $32 \%$ \\
\hline \multirow{2}{*}{ Aplikasi yang digunakan } & Kreditpintar & $\mathbf{7 2}$ & $\mathbf{3 5 , 5 \%}$ \\
& Traveloka Paylater & 46 & $22,7 \%$ \\
& Akulaku & 34 & $16,7 \%$ \\
& Uangteman & 17 & $8,4 \%$ \\
& Kredivo & 11 & $5,4 \%$ \\
& Tunaiku & 7 & $3,4 \%$ \\
& Cicil & 5 & $2,5 \%$ \\
& Incash & 5 & $2,5 \%$ \\
& Julo & 2 & $1 \%$ \\
& KreditQ & 2 & $1 \%$ \\
& DanaCepat & 2 & $1 \%$ \\
\hline
\end{tabular}

Tabel 3. Demografi Responden Non User

\begin{tabular}{llll}
\hline \multirow{2}{*}{ Jenis Kelamin } & Laki-laki & $\mathbf{6 9}$ & $\mathbf{6 1 \%}$ \\
& Perempuan & 45 & $39 \%$ \\
\hline \multirow{2}{*}{ Usia } & $<17$ th & 1 & $1 \%$ \\
& 20-25th & $\mathbf{4 6}$ & $\mathbf{4 0 \%}$ \\
& 26-30th & 38 & $33 \%$ \\
& 31-40th & 21 & $19 \%$ \\
& 41-50th & 7 & $6 \%$ \\
& $>$ 50th & 1 & $1 \%$ \\
\hline \multirow{2}{*}{ Wilayah } & Papua & $\mathbf{2 4}$ & $\mathbf{2 7 , 3 \%}$ \\
& D.I.Yogyakarta & 23 & $26,2 \%$ \\
& Jawa Tengah & 20 & $22 \%$ \\
& & &
\end{tabular}




$\begin{array}{lll}\text { Jawa Barat } & 12 & 13,6 \% \\ \text { Kalimantan Utara } & 11 & 12,5 \% \\ \text { DKI Jakarta } & 5 & 5,7 \% \\ \text { Jawa Timur } & 4 & 4,5 \% \\ \text { Riau } & 3 & 3,4 \% \\ \text { Sumatera Barat } & 2 & 2,2 \% \\ \text { Sumatera Selatan } & 2 & 2,2 \% \\ \text { Kalimantan Barat } & 1 & 1,1 \% \\ \text { Kalimantan Tengah } & 1 & 1,1 \% \\ \text { Kalimantan Timur } & 1 & 1,1 \% \\ \text { Makassar } & 1 & 1,1 \% \\ \text { Sumatera Utara } & 1 & 1,1 \% \\ \text { Bengkulu } & 1 & 1,1 \% \\ \text { Sulawesi Tengah } & 1 & 1,1 \% \\ \text { Sulawesi Tenggara } & 1 & 1,1 \%\end{array}$

Berdasarkan data responden, terdapat 114 responden yang tidak menggunakan aplikasi peer to peer lending. Sebagian besar non user aplikasi peer to peer lending berjenis kelamin laki-laki dengan jumlah 69 responden. Berdasarkan usia, sebagian besar non user berusia 20-25th dengan jumlah 46 user, dan berdasarkan wilayah sebagian besar non user wilayah Papua dan Yogyakarta seperti yang ditampilkan pada tabel Tabel 3.

\subsection{Hasil Analisis Statistik}

Uji validitas dalam penelitian ini dilakukan dengan menggunakan alat bantu atau tools aplikasi SPSS 25.0 berdasarkan hasil uji validitas dapat disimpulkan bahwa terdapat satu indikator yang tidak valid yaitu indikator CBT04 (Aplikasi peer to peer lending yang digunakan sepenuhnya kompatibel) nilai $R_{\text {hitung }}$ sebesar $0,58<0,60$ yang artinya indikator dinyatakan tidak valid sehingga item pernyataan dibuang, kemudian diuji kembali. Hasil uji validitas menunjukkan bahwa keseluruhan dinyatakan valid. Sedangkan berdasarkan hasil uji reliabilitas, maka dapat disimpulkan bahwa seluruh variabel dependent dan variabel independent dikatakan realibel karena memiliki nilai $>0,60$.

Berdasarkan hasil uji normalitas menunjukkan bahwa nilai signifikansi (Sig.) sebesar 0,20 yang artinya lebih besar dari 0,05 sehingga data pada penelitian ini dinyatakan berdistribusi normal dan telah memenuhi syarat untuk dapat digunakan sebagai analisis regresi berganda. Selanjutnya hasil uji multikolinearitas tolerance lebih dari 0,10 dan VIF kurang dari 10,00 sehingga dikatakan bahwa tidak terjadi multikolinearitas dalam regresi. Selanjutnya asumsi ini telah memenuhi persyaratan untuk analisis regresi berganda, dan hasil uji hesteroskedastisitas glejser menunjukkan bahwa nilai signifikansi lebih besar dari 0,05 sehingga dapat dikatakan model dalam regresi tidak terjadi gejala heteroskedastisitas.

Berdasarkan hasil uji F menunjukkan bahwa hasil signifikasi (Sig.) adalah sebesar 0,000 yang artinya < 0,05 sehingga dikatakan bahwa relative advantage, compatibility, complexity, trialability, dan observability secara simultan berpengaruh terhadap variabel intensi. Selanjutnya hasil uji determinasi diketahui bahwa nilai koefisien korelasi ( $\mathrm{R}$ squre) adalah sebesar 0,859. Nilai tersebut berasal dari pengkuadratan nilai koefisien korelasi $(\mathrm{R})$ yaitu $0,927 \times 0,927=0,859$ atau sama dengan $85,9 \%$. Dengan demikian dapat diartikan bahwa model PCI dengan variabel relative advantage, compatibility, complexity, trialability, dan observability secara simultan atau bersama-sama berpengaruh $85,9 \%$ terhadap intensi sedangkan sisanya $(100 \%-85,9 \%=14,1 \%)$ dipengaruhi oleh variabel lain yang tidak diteliti dalam penelitian ini. Berdasarkan hasil uji asumsi klasik, maka model regresi yang digunakan secara keseluruhan telah memenuhi persyaratan. Kemudian dilakukan analisis regresi linear berganda untuk menguji hipotesis dalam penelitian ini. Adapun hasil uji analisis regresi berganda dapat dilihat pada Tabel 4.

Tabel 4. Hasil Uji Regresi

\begin{tabular}{lrrc}
\hline \multicolumn{1}{c}{ Model } & Koefisien & \multicolumn{1}{c}{ T } & Sig. \\
\hline (Constant) & $-0,870$ &,- 509 & 0,612 \\
Relative advantage & 0,643 & 9,743 & $\mathbf{0 , 0 0 0}$ \\
Compatibility & $-0,069$ & $-1,268$ & 0,206 \\
Complexity & $-0,190$ & $-3,578$ & $\mathbf{0 , 0 0 0}$ \\
Trialability & $-0,230$ & $-1,578$ & 0,116 \\
Observability & 0,638 & 6,200 & $\mathbf{0 , 0 0 0}$ \\
\hline
\end{tabular}

\subsection{Pembahasan}

Berdasarkan Tabel 4 maka dapat dilihat bahwa terdapat variabel relative advantage, complexity, dan obersevability yang nilainya lebih kecil daripada 0,05 sehingga dikatakan terdapat pengaruh antara intensi 
ISSN 2614-5278 (media cetak), ISSN 2548-8368 (media online)

Available Online at https://ejurnal.stmik-budidarma.ac.id/index.php/mib DOI $10.30865 /$ mib.v4i2.2059

penggunaan aplikasi. Kemudian hasil menunjukkan terdapat dua variabel independent yaitu compatibility dan trialability yang nilainya lebih besar dari 0,05 sehingga dikatakan bahwa variabel tersebut tidak berpengaruh terhadap intensi penggunaan aplikasi peer to peer lending fintech.

Pertama, berdasarkan Tabel 4 menunjukkan bahwa terdapat pengaruh positif dan signifikan antara relative advantage terhadap intensi penggunaan aplikasi peer to peer lending fintech. Hal ini berarti $\mathrm{H} 1$ diterima. Sejalan dengan penelitian [17] yang menunjukkan bahwa relative advantage berpengaruh terhadap adopsi Mobile Banking untuk nasabah BCA di Surabaya. Selain itu hasil penelitian [18] memberikan penjelasan yang relevan terkait dengan sebuah inovasi, karena semakin tinggi keuntungan relatif (relative advantage) dari inovasi, maka semakin besar kemungkinan seseorang akan mengadopsi inovasi. Berdasarkan hasil wawancara, salah satu relative advantage pada aplikasi peer to peer lending adalah dapat digunakan sebagai salah satu sumber dana cadangan saat kebutuhan mendadak (kreditpintar), pada aplikasi lain seperti traveloka paylater dapat memperoleh keuntungan dengan cepat membeli tiket terlebih dahulu tanpa harus membayar pada hari itu juga. Tiket dapat dibayarkan dengan waktu dan cicilan sesuai ketentuan traveloka. Begitu juga dengan layanan akulaku, user dapat membeli barang-barang yang diinginkan tanpa harus membayar terlebih dahulu. Dengan demikian hasil penelitian menunjukkan bahwa ada pengaruh yang positif dan signifikan antara relative advantage terhadap intensi penggunaan aplikasi peer to peer lending fintech, artinya semakin tinggi keuntungan relatif maka intensi penggunaan aplikasi peer to peer lending fintech semakin meningkat.

Kedua, berdasarkan Tabel 4 menunjukkan bahwa tidak ada pengaruh yang positif dan signifikan antara compatibility terhadap intensi penggunaan aplikasi peer to peer lending fintech. Hal ini berarti $\mathrm{H} 2$ ditolak. Sejalan dengan penelitian [9] yang menunjukkan bahwa compatibility tidak memiliki pengaruh signifikan terhadap niat mengadopsi Solopos epaper. Namun berbeda dengan penelitian yang mengatakan bahwa compatibility berpengaruh terhadap niat penggunaan mobile banking BRI bahkan [19] menunjukkan hasil bahwa compatibility berpengaruh paling besar terhadap sikap adopsi e-learning. Berdasarkan hasil penelitian ini, compatibility tidak berpengaruh positif dan signifikan terhadap intensi penggunaan aplikasi peer to peer lending fintech. Kesesuaian (compatibility) dirasakan tidak dapat meningkatkan intensi penggunaan aplikasi peer to peer lending fintech karena persyarataan yang diajukan oleh investor tidak sesuai dengan kreditur, misalnya terlalu banyak tahap-tahap yang dilalui untuk mendapatkan persetujuan pencairan dana, tagihan dan bunga tidak sesuai. Selain itu tidak sesuai gaya hidup, dan aturan yang berkaitan dengan keyakinan (agama) seperti dilarang adanya transaksi yang berhubungan dengan riba, yakni transaksi tersebut adanya fasitilitas pengembalian dana yang melebihi jumlah pinjaman atau yang biasa disebut dengan bunga.

Ketiga, berdasarkan Tabel 4 menunjukkan bahwa terdapat pengaruh yang negatif dan signifikan antara complexity terhadap intensi penggunaan aplikasi peer to peer lending fintech. Hal ini berarti $\mathrm{H} 3$ diterima. Hasil penelitian ini sejalan dengan penelitian [20] bahwa complexity berpengaruh negatif terhadap niat penggunaan Mobile Banking BRI. Berbeda dengan penelitian [19] yang menunjukkan hasil bahwa complexity tidak berpengaruh terhadap sikap adopsi e-learning. Sejalan dengan hasil penelitian pada Tabel 5 yang menunjukkan bahwa beberapa masyarakat masih merasakan rumitnya menggunakan aplikasi pinjaman online, artinya semakin rendah kompleks (complexity) sebuah aplikasi maka intensi penggunaan aplikasi peer to peer lending fintech semakin meningkat. Sebaliknya jika semakin tinggi kompleksitas (complexity) maka akan semakin meningkat pula intensi penggunaan aplikasi peer to peer lending fintech sehingga pihak startup perlu lebih memperhatikan bahwa sistem harus sangat user friendly.

Keempat, berdasarkan tabel Tabel 4 menunjukkan bahwa tidak ada pengaruh yang positif dan signifikan antara trialability terhadap intensi penggunaan aplikasi peer to peer lending fintech. Hal ini berarti $\mathrm{H} 4 \mathrm{ditolak}$. Sejalan dengan penelitian [19] yang mengatakan bahwa trialability tidak berpengaruh positif dan signifikan terhadap sikap adopsi e-learning. Berdasarkan hasil penelitian menunjukkan bahwa tidak ada pengaruh yang positif dan signifikan antara trialability terhadap intensi penggunakaan aplikasi peer to peer lending fintech. Trialability (uji coba) dirasakan masyarakat tidak dapat meningkatkan intensi penggunaan aplikasi peer to peer lending fintech karena tidak semua aplikasi menyediakan layanan uji coba transaksi bagi pemula dan kurang optimal dalam menyediakan tutorial pengunaan aplikasi baik berupa dokumen maupun video sehingga mudah bagi user mendapatkan cairan dana tanpa berfikir panjang dalam membayar tagihan.

Kelima, pada Tabel 4 menunjukkan bahwa ada pengaruh yang positif dan signifikan antara observability terhadap intensi penggunaan aplikasi peer to peer lending fintech. Hal ini berarti H5 diterima. Sejalan dengan penelitian [20] yang mengatakan bahwa observability berpengaruh positif dan signifikan terhadap niat penggunaan mobile banking BCA. Dari hasil wawancara, cara mengkomunikasikan aplikasi kepada orang lain berpengaruh karena responden mendapatkan pengetahuan lebih banyak terkait dengan aplikasi peer to peer lending sehingga jika responden membutuhkan dana cepat, akan berniat menggunakan aplikasi tersebut. Berdasarkan hasil penelitian menunjukkan bahwa ada pengaruh yang positif dan signifikan antara observability terhadap intensi penggunakaan aplikasi peer to peer lending fintech, artinya semakin tinggi sebuah aplikasi mampu diujicoba maka intensi penggunaan aplikasi peer to peer lending fintech semakin meningkat.

\subsection{Analisis Faktor-Faktor Non User}

Analisis dilakukan untuk mengetahui gambaran jawaban responden non user secara detail terhadap aplikasi peer to peer lending fintech. Pada analisis ini, akan menampilkan jawaban deskriptif responden. Adapun jawaban 
tersebut telah disediakan jawaban alternatif oleh peneliti, selain itu responden juga dapat menjawab secara deskriptif sesuai jawaban yang diinginkan. Dari hasil jawaban tersebut, peneliti memberikan kode mendapatkan hasil dari responden. Dalam hal ini responden boleh menjawab lebih dari satu jawaban.

1. Faktor yang mempengaruhi Non User : berdasarkan jawaban responden, maka diperoleh hasil faktor-faktor yang mempengaruhi masyarakat tidak menggunakan aplikasi. Responden terbanyak mengatakan bahwa tidak tertarik dalam menggunakan aplikasi peer to peer lending. Selanjutnya faktor yang mempengaruhi masyarakat tidak menggunakan aplikasi dapat dilihat pada Tabel 5. Kemudian dikuatkan lagi dengan hasil wawancara bahwa masyarakat tidak tertarik menggunakan aplikasi peer to peer lending fintech kurangnya pemahaman masyarakat awam terkait dengan aplikasi tersebut, mereka merasa rumitnya menggunakan aplikasi itu karena merasa belum dapat memenuhi persyaratan yang diajukan startup dibandingkan dengan persyaratan bank konvensional yang sudah jelas dan tidak berubah.

Tabel 5. Faktor yang Mempengaruhi NonUser

\begin{tabular}{lc}
\hline \multicolumn{1}{c}{ Faktor Non User } & Jumlah \\
\hline Tidak tertarik mendengar tentang aplikasi tersebut & 45 \\
Belum pernah menden & 42 \\
Rumit & 23 \\
Tidak mau berurusan dengan lembaga keuangan & 14 \\
Bertentangan dengan agama & 11 \\
Tidak tahu & 6 \\
Bunganya tinggi & 3 \\
Legalitas hukumnya belum sekuat konvensional & 1 \\
\multicolumn{2}{c}{ Total } \\
\hline
\end{tabular}

2. Hasil Analisis Solusi Mendapatkan Pinjaman Selain Peer to peer lending Fintech: berdasarkan hasil jawaban kuesioner responden maka diperoleh hasil perangkingan masyarakat masih meminjam saudara/teman/ keluarga pada Tabel 6. Dari hasil wawancara kepada beberapa responden, masyarakat lebih memilih meminjam saudara/teman/keluarga karena lebih aman dan cepat mendapatkan. Kemudian alasan mereka lebih memilih meminjam Bank karena lebih nyaman dan Bank menyediakan jumlah pinjaman yang besar dengan bunga yang sedikit/kecil.

Tabel 6. Solusi Pinjaman Selain Aplikasi Peer to peer lending Fintech

\begin{tabular}{lc}
\hline \multicolumn{1}{c}{ Solusi Pinjaman } & Jumlah \\
\hline Meminjam saudara/teman/keluarga & 75 \\
Bank & 38 \\
Koperasi Unit & 7 \\
Pegadaian & 3 \\
Menabung & 2 \\
Meminjam lembaga keuangan syari'ah & 1 \\
Saham \& forex & 1 \\
Menjual barang berharga & 1 \\
Total & 128 \\
\hline
\end{tabular}

\section{KESIMPULAN}

Karakteristik yang menjadi penentu intensi penggunaan aplikasi peer to peer lending fintech adalah relative advantage, complexity, dan obervability. Sedangkan faktor-faktor yang tidak menjadi penentu intensitas penggunaan aplikasi peer to peer lending fintech adalah compatibility dan trialability. Kontribusi yang diberikan variabel independent terhadap variabel dependent adalah sebesar 85,9\% sedangkan sisanya $100 \%-85,9 \%=$ $14,1 \%$ dipengaruhi oleh variabel lain yang tidak diteliti, yang artinya bahwa model PCI berkontribusi besar terhadap variabel intensi penggunaan aplikasi. Kemudian Faktor-faktor yang menyebabkan masyarakat tidak menggunakan aplikasi peer to peer lending fintech adalah kurangnya ketertarikan masyarakat dalam menggunakan aplikasi, masyarakat belum pernah mendengar tentang aplikasi peer to peer lending, belum pernah mendengar tentang aplikasi tersebut, dirasa rumit, selain itu mereka tidak mau berurusan dengan lembaga keuangan, beberapa masyarakat beranggapan bahwa menggunakan aplikasi peer to peer lending bertentangan dengan agama, tidak tau sama sekali terkait dengan aplikasi peer to peer lending, bunganya tinggi dan masyarakat mengatakan bahwa legalitas hukum belum sekuat konvensional. 
JURNAL MEDIA INFORMATIKA BUDIDARMA

Volume 4, Nomor 2, April 2020, Page 421-428

ISSN 2614-5278 (media cetak), ISSN 2548-8368 (media online)

Available Online at https://ejurnal.stmik-budidarma.ac.id/index.php/mib

DOI 10.30865/mib.v4i2.2059

\section{UCAPAN TERIMAKASIH}

Terima kasih kami sampaikan kepada Universitas Amal Ilmiah Yapis Wamena yang telah bersedia memberikan bantuan dana publikasi pada penelitian ini dan kepada Universitas Islam Indonesia Yogyakarta atas bantuan penulisan dan pelaksanaan penelitian.

\section{REFERENCES}

[1] P. Gomber, R. J. Kauffman, C. Parker, and B. W. Weber, "On the Fintech Revolution: Interpreting the Forces of Innovation, Disruption, and Transformation in Financial Services,” J. Manag. Inf. Syst., vol. 35, no. 1, pp. 220-265, 2018.

[2] E. Z. Milian, M. de M. Spinola, and M. M. de Carvalho, "Fintechs: A Literature Review and Research Agenda," Electron. Commer. Res. Appl., pp. 1-58, 2019.

[3] B. A. Wicaksono and I. Krisnadi, "Analisis Pengembangan Strategi Bisnis Perusahaan Fintech Di Indonesia ( Studi Kasus pada PT . Amartha Mikro Fintek ) Analysis of Fintech Company' s Business Strategy Development in Indonesia ( case study at PT Amartha Mikro Fintek )," Manaj. Telekomun. Univ. Indones., pp. 1-8, 2018.

[4] C. N. Nababan, "Pinjaman Online per Juni 2019 Tembus Rp44,80 Triliun," 2019. [Online]. Available: https://www.cnnindonesia.com/ekonomi/20190812084635-78-420402/pinjaman-online-per-juni-2019-tembus-rp4480triliun. [Accessed: 22-Dec-2019].

[5] Dailysocial, "Fintech Report 2018 - Daily Social," pp. 1-40, 2018.

[6] DetikFinance, "144 Pinjaman Online Ilegal Ditutup, Ini Daftarnya," 29 April 2019, 2019. [Online]. Available: https://finance.detik.com/moneter/d-4528597/144-pinjaman-online-ilegal-ditutup-ini-daftarnya. [Accessed: 26-Jun2019].

[7] Tempo, "Viral Wanita Rela Digilir untuk Bayar Utang Fintech, Sikap OJK? - Bisnis Tempo.co," 24 Juli $2019,2019$. [Online]. Available: https://bisnis.tempo.co/read/1228064/viral-wanita-rela-digilir-untuk-bayar-utang-fintech-sikap-ojk. [Accessed: 02-Aug-2019].

[8] E. M. Rogers, "A prospective and retrospective look at the diffusion model," J. Health Commun., vol. 9, no. November, pp. 13-19, 2004

[9] Sholahuddin, "Pengaruh Karakteristik Inovasi Terhadap Niat Mengadopsi Solopos E-Paper," Management, pp. 1-34, 2017.

[10] P. Schueffel, "Taming the Beast: A Scientific Definition of Fintech," J. Innov. Manag., vol. 4, no. 4, pp. 32-54, 2016.

[11] H. Gunawan, "Fenomena Startup Fintech dan Implikasinya," Swara Patra, vol. 8, no. 4, pp. 44-55, 2018.

[12] R. Ge, J. Feng, B. Gu, and P. Zhang, "Predicting and Deterring Default with Social Media Information in Peer-to-Peer Lending," J. Manag. Inf. Syst., vol. 34, no. 2, pp. 401-424, 2017.

[13] I. Ilahiyah, "Analisis Konsep Islamic Peer to Peer Lending Financing sebagai Alternatif Pemberdayaan Usaha Mikro Kecil dan Menengah," Ekon. dan Bus., vol. 66, no. 2, pp. 37-39, 2018.

[14] F. Wahid and L. Iswari, “Adopsi Teknologi Informasi Oleh Usaha Kecil dan Menengah di Indonesia," Semin. Nas. Apl. Teknol. Inf., vol. 2007, no. Snati, pp. 75-79, 2007.

[15] E. M. Rogers, A. Singhal, and M. M. Quinlan, Diffusion of innovations. New York: Free Press, 1995.

[16] Sugiyono, Metode Penelitian Kuantitatif, Kualitatif, dan R \& D. Bandung: Alfabeta, 2017.

[17] N. D. Tristiyanti, "Pengaruh Keunggulan Relatif, Kompatibilitas, Persepsi Kegunaan, Kemampuan Untuk Dilihat, dan Persepsi Resiko Terhadap Adopsi Mobile Banking Bagi Nasabah BCA di Surabaya," Management, pp. 2-4, 2017.

[18] Q. He, Y. Duan, Z. Fu, and D. Li, "An innovation adoption study of online e-payment in Chinese companies," $J$. Electron. Commer. Organ., vol. 4, no. 1, pp. 48-69, 2006.

[19] L. Kusdibyo and G. Leo, “Adopsi Inovasi E-Learning di Perguruan Tinggi,” Ind. Res. Work. Nation Semin., 2017.

[20] D. Wulandari, "Pengaruh Inovasi Produk (Keuntungan Relatif, Kompabilitas, dan Kompleksitas) Terhadap Niat Penggunaan Mobile Banking BRI (Studi pada Agen LPG 3 Kg di Bandar Lampung),” Universitas Lampung, 2017. 